\title{
IMPLEMENTASI SOSIALISASI COVID-19 DALAM UPAYA MENINGKATKAN KESADARAN MASYARAKAT TERHADAP PROTOKOL KESEHATAN DI KOTA JAKARTA
}

\section{THE SOCIALIZATION OF COVID-19 AS AN EFFORT TO INCREASE COMMUNITY AWARENESS ON HEALTH PROTOCOLS IN JAKARTA}

\author{
Rafi Ramadhani Elgaputra ${ }^{1}$, Evan Yoga Adhi Sakti ${ }^{2}$, Dahayu Bethari Widyandri ${ }^{2}$, \\ Alifia Riza Azhari ${ }^{2}$, Claudia Renatta ${ }^{3}$, Kirania Rainasya ${ }^{3}$, Kiagus Sulthan \\ Madani $^{1}$, Sabhinaya Vanyaska Gitawangi ${ }^{4}$, Faradita ${ }^{4}$, Shabrina Aulia Pradyanti ${ }^{5}$, \\ Sri Musta'ina ${ }^{6}$ \\ ${ }^{1}$ Departemen Ilmu Administrasi Negara, Fakultas Ilmu dan Politik, ${ }^{2}$ Departemen \\ Ekonomi Syariah, Fakultas Ekonomi dan Bisnis, ${ }^{3}$ Departemen Ilmu Komunikasi, \\ Fakultas Ilmu dan Politik, ${ }^{4}$ Departemen Kesehatan Masyarakat, Fakultas Kesehatan \\ Masyarakat, ${ }^{5}$ Departemen Psikologi, Fakultas Psikologi, ${ }^{6}$ Departemen Biologi \\ Kedokteran, Fakultas Kedokteran Universitas Airlangga \\ email : rafi.ramadhani.elgaputra-2017@ fisip.unair.ac.id
}

\begin{abstract}
In carrying out the 62nd Kuliah Kerja Nyata (KKN) of Universitas Airlangga, group 270 raised the theme 'Socialization of COVID-19 in an Effort to Increase Public Awareness of Health Protocols' with a target of 500 active users of Instagram social media and the people of Cempaka Putih Barat Village, Cempaka Putih District. , Central Jakarta. The 270 group chose Instagram because it is a trend in a society where the majority use Instagram as a media to search and find all information. Meanwhile, Cempaka Putih Subdistrict was chosen as the target because the sub-district ranks fifth in the red zone in Jakarta.There are 4 activities that we do online and one activity offline. Online activities include group discussions recorded through online meeting platforms and short videos related to things that need to be done and prepared for activities outside the home in the New Normal era. Then, we also recorded online discussions in collaboration with the Team of Medical Doctors, Faculty of Medicine, Airlangga University, Surabaya.
\end{abstract}

Keywords: Covid-19, discussion, online, socialization

abstrak

Dalam melaksanakan Kuliah Kerja Nyata (KKN) Ke-62 Universitas Airlangga, kelompok 270 mengangkat tema 'Sosialisasi COVID-19 dalam Upaya Meningkatkan Kesadaran Masyarakat Terhadap Protokol Kesehatan' dengan sasaran 500 pengguna aktif media sosial Instagram dan masyarakat Kelurahan Cempaka Putih Barat, Kecamatan Cempaka Putih, Jakarta Pusat. Kelompok 270 memilih Instagram karena menjadi trend dalam masyarakat yang mayoritas menggunakan Instagram sebagai media untuk mencari dan menemukan segala informasi. Sedangkan pemilihan Kecamatan Cempaka Putih sebagai sasaran karena seperti yang disebutkan sebelumnya, kecamatan tersebut menempati urutan kelima zona merah di Jakarta. Terdapat 4 kegiatan yang kami lakukan secara daring dan satu kegiatan secara luring. Kegiatan daring berupa diskusi kelompok yang direkam melalui platform meeting online dan video singkat terkait hal yang perlu dilakukan dan dipersiapkan untuk beraktivitas di luar rumah pada era New Normal. Kemudian, kami juga melakukan rekaman diskusi daring berkolaborasi dengan Tim Dokter Fakultas Kedokteran Universitas Airlangga, Surabaya.

Kata kunci : Covid-19, diskusi, daring, sosialisasi. 
Rafi Ramadhani Elgaputra, dkk: Implementasi Sosialisasi Covid-19 dalam Upaya Meningkatkan Kesadaran Masyarakat Terhadap Protokol Kesehatan di Kota Jakarta

\section{PENDAHULUAN}

Penyakit yang disebabkan oleh virus SARS-CoV 2, yaitu COVID-19 telah membuat dunia menjadi resah. Pandemi ini tidak hanya menyerang Indonesia namun juga menyerang di berbagai negara. Sehingga WHO menyatakan Covid-19 sebagai pandemi dan memberlakuan darurat kesehatan global, serta menyerukan tindakan pemutusan rantai penularan secara internasional. Penyebaran penyakit ini sangat cepat, ditandai dengan penambahan jumlah kasus dan jumlah kematian. Sejak pebruari 2020 sampai dengan juli 2020, pertambahan kasus yang terjadi terus meningkat di Indonesia, khususnya di Kota DKI Jakarta, memberikan gambaran bahwa kondisi di Indonesia masih belum terbebas dari COVID-19. Kurangnya kepatuhan masyarakat terhadap peraturan serta protokol kesehatan COVID-19 yang telah ditetapkan oleh pemerintah diakibatkan oleh bias kognitif yang merupakan kesalahan sistematis dalam berpikir yang mempengaruhi keputusan dan penilaian yang dibuat oleh seseorang. Penyebaran ini sudah semakin meluas diseluruh propinsi di Indonesia. Walaupun terbilang Indonesia agak terlambat dalam menangani kasus COVID-19 ini, berbagai upaya harus dilakukan oleh Pemerintah dalam menghadapi kasus ini.

Sesuai dengan Keputusan Gubernur Daerah Khusus Ibukota Jakarta Nomor 563 Tahun 2020 Tentang Pemberlakuan, Tahapan Dan Pelaksanaan Kegiatan/Aktivitas Pembatasan Sosial Berskala Besar Pada Masa Transisi Menuju Masyarakat Sehat, Aman Dan Produktif, Gubernur DKI Jakarta, Anies Baswedan menetapkan pemberlakuan PSBB Transisi yang merupakan periode transisi dari masa pembatasan sosisal berskala besar (PSBB) menuju kembalinya kegiatan sosial ekonomi. Beberapa kegiatan sosial ekonomi pun mulai dibuka secara bertahap dengan batasan dan protokol kesehatan COVID-19 pada masa PSBB Transisi. Namun, banyak masyarakat yang tidak menyikapi hal ini dengan baik, salah satunya yakni menggunakan waktu bekerja dan sekolah dari rumah (work from home) untuk berlibur. Selain itu, masih banyak masyarakat Jakarta yang menganggap remeh keberadaan virus ini dengan tidak menaati peraturan serta protokol kesehatan yang sudah ditetapkan oleh pemerintah propinsi DKI Jakarta.

Melihat adanya pertambahan kasus yang terus meningkat di Kota DKI Jakarta per bulan juli 2020 ini, memberikan gambaran bahwa kondisi DKI Jakarta masih belum terbebas dari COVID-19. Kurangnya kepatuhan masyarakat terhadap peraturan serta protokol kesehatan COVID-19 yang telah ditetapkan oleh pemerintah diakibatkan oleh bias kognitif yang merupakan kesalahan sistematis dalam berpikir yang mempengaruhi keputusan dan penilaian yang dibuat oleh seseorang. Sejalan dengan teori efek Dunning-Kruger yang menyatakan bahwa orang yang memiliki cukup pengetahuan dan referensi literatur akan dapat mematuhi dan melaksanakan anjuran pemerintah dengan baik dan maksimal, sehingga dapat disimpulkan bahwa kemampuan literasi serta minimnya akses informasi terhadap informasi terkait COVID-19 mengakibatkan masyarakat cenderung mengindahkan himbauan pemerintah.

Hal ini terjadi salah satunya di wilayah Jakarta yang terdampak COVID-19 yaitu Cempaka Putih. Menurut data per Juli 2020, Cempaka Putih menempati urutan ke-5 zona merah di Jakarta setelah Pademangan, Penjaringan, Sunter Agung dan Sunter Jaya. Dalam menghadapi pandemi COVID-19, dibutuhkan kesiapan dan kesigapan pemerintah dalam menangani COVID-19. Pemerintah juga harus dibantu dengan kesadaran dari masyarakat. Masyarakat dihimbau untuk membantu upaya pemerintah memutus penyebaran COVID-19 dengan diam di rumah, dan masing-masing individu 
menerapkan protokol pencegahan. Namun pada kenyataan di daerah tersebut dan seluruh wilayah di DKI Jakarta sampai saat ini merupakan zona merah.

Data tersebut berkaitan dan juga sejalan dengan teori efek yang dipaparkan sebelumnya, yaitu teori efek Dunning-Kruger, masyarakat Indonesia yang tidak mengindahkan himbauan pemerintah, memiliki bias kognitif ini, dimana mereka merasa lebih mengerti kondisi pandemi virus ini, padahal pada kenyataannya itu adalah kesalahan (Dana Riska Buana, 2020). Contohnya mereka merasa dapat menjaga diri dengan baik walaupun berada di luar rumah atau di keramaian, jadi mereka akan merasa pintar atas dasar persepsi mereka sendiri. Fenomena ini dapat terjadi disebabkan rendahnya kemampuan literasi maupun masih banyak orang yang tidak memiliki akses pada media-media informasi sehingga mereka memiliki minim pengetahuan atas merebaknya wabah COVID-19 ini. Sejalan dengan teori efek Dunning-Kruger maka orang yang memiliki cukup pengetahuan dan referensi literatur akan dapat mematuhi dan melaksanakan anjuran pemerintah dengan baik dan maksimal.

Menurut Kahneman (2011), untuk mengatasi bias tersebut salah satunya dapat dilakukan dengan cara berpikir berdasarkan data dan fakta. Dengan mengerti data-data ataupun fakta yang ada pada kondisi yang sedang dihadapi maka secara kognisi seseorang dapat melihatnya dalam kondisi yang lebih tajam dan luas, sehingga kesalahan dalam mengambil keputusan tidak terjadi. Seperti apa yang telah disinggung pada sub bab sebelumnya, rendahnya kemampuan literasi dan masih banyak orang yang tidak memiliki akses pada media informasi menyebabkan mereka memiliki pengetahuan yang minim atas pandemi COVID-19. Hal ini dapat diatasi dengan memperkaya ilmu dan pengetahuan seperti apa yang dikatakan Kahneman di atas. Dengan begitu orang yang memiliki cukup pengetahuan dan referensi literatur akan dapat memahami dan melaksanakan anjuran pemerintah dengan baik dan maksimal. Kelompok 270 grup 8 KKN-BBM ke 62 Universitas Airlangga merencanakan rangkaian kegiatan penyuluhan kepada masyarakat DKI Jakarta yang bertemakan : Pentingnya Penerapan Protokol Kesehatan untuk memutus rantai penularan COVID-19 menggunakan platform media sosial sebagai media edukasi.

Virus Corona atau disebut pula COVID-19 (Coronavirus Disease 2019) ditemukan pertama kali di Kota Wuhan, China pada akhir Desember 2019 (Yunus \& Rezki, 2020). Wabah ini telah ditetapkan sebagai darurat kesehatan global. Virus ini sempat membuat semua kegiatan sehari-hari manusia terhambat. Karantina saja mungkin tidak cukup untuk mencegah penyebaran virus COVID-19 ini, dan dampak global dari infeksi virus ini adalah salah satu yang semakin memprihatinkan (Sohrabi et al., 2020)

Menurut Buana (2020) dijelaskan bahwa protokol kesehatan wajib diterapkan selama masa pandemi. Suni (2020) juga menjelaskan protokol kesehatan untuk penanggulangan COVID-19 terdiri dari fase pencegahan, fase deteksi dan fase respon. Sependapat dengan Buana dan Suni, protokol kesehatan menjadi penting mengingat kita sudah memasuki era new normal pasca COVID-19. Peran dari pemerintah dan juga masyarakat sangat dibutuhkan untuk mengurangi penularan yang lebih banyak. Kementerian Kesehatan RI (2020) juga mengeluarkan pedoman kesiapsiagaan dalam menghadapi penyebaran COVID-19. Upaya yang dapat dilakukan pada fase pencegahan oleh setiap individu antara lain: Memakai masker, Memakai sarung tangan, Menggunakan hand sanitizer/desinfektan, Mencuci tangan dengan sabun, Menghindari 
Rafi Ramadhani Elgaputra, dkk: Implementasi Sosialisasi Covid-19 dalam Upaya Meningkatkan Kesadaran Masyarakat Terhadap Protokol Kesehatan di Kota Jakarta

menyentuh wajah, Menghindari berjabat tangan, Menghindari pertemuan atau antrian Panjang, Menghindari menyentuh benda/permukaan benda di area publik, Menghindari naik transportasi umum, Menjaga jarak setidaknya dua meter dari orang lain ketika di luar rumah, dan Jika menunjukkan gejala penyakit segera mendatangi fasiltas kesehatan terdekat.

Tukan (2020) berpendapat masih banyak masyarakat yang 'bandel' di era pandemi COVID-19 ini. Masyarakat 'bandel' ini perlu diberikan pemahaman khusus tentang COVID-19. Baik dari cara penularannya, cara menghindari penularannya, dampak dan bahaya yang ditimbulkan dan resiko besar yang berujung kematian. Sependapat dengan Tukan bahwa pemahaman dan kesadaran khususnya bagi masyarakat yang bandel yang tidak betah dirumah dan masih bepergian keluar rumah tanpa menggunakan masker yang beresiko menularkan kepada orang lain. Menunda untuk tidak keluar rumah demi mengurangi interaksi dengan orang lain. Apabila terpaksa harus keluar rumah, maka terapkan protokol kesehatan seperti menjaga jarak, rutin mencuci tangan atau menggunakan hand sanitizer, dan menggunakan masker (Pane, 2020).

\section{METODE PENGABDIAN MASYARAKAT}

Adanya pandemi COVID-19 menyebabkan dunia harus banyak beradaptasi dalam menjalankan kegiatannya. Segala bentuk kegiatan yang dilakukan harus mematuhi dan mempertimbangkan protokol kesehatan sebagai tindakan pemutusan penularan Virus Corona, termasuk sistem pendidikan di Indonesia. Hal tersebut menyebabkan perguruan tinggi harus melakukan pembelajaran jarak jauh secara daring demi mendukung pemutusan penularan Virus Corona tersebut. Tidak terkecuali dengan program Kuliah Kerja Nyata $(\mathrm{KKN})$ yang setiap semester rutin dilaksanakan oleh mahasiswa perguruan tinggi pun harus dilaksanakan secara daring.

Dalam menyukseskan pelaksanaan Kuliah Kerja Nyata (KKN) Ke 62 Universitas Airlangga, kelompok 270 mengangkat tema 'Sosialisasi COVID-19 dalam Upaya Meningkatkan Kesadaran Masyarakat Terhadap Protokol Kesehatan' dengan sasaran 500 pengguna aktif media sosial Instagram dan masyarakat Kelurahan Cempaka Putih Barat, Kecamatan Cempaka Putih, Jakarta Pusat. Kelompok 270 memilih media sosial Instagram sebagai sarana publikasi karena melihat trend dalam masyarakat yang mayoritas menggunakan Instagram sebagai media untuk mencari dan menemukan segala informasi. Sedangkan pemilihan Kecamatan Cempaka Putih sebagai sasaran karena seperti yang disebutkan sebelumnya, kecamatan tersebut menempati urutan ke-5 zona merah di Jakarta.

Terdapat 4 (empat) intervensi yang kami lakukan secara dalam jaringan (daring) dan 1 (satu) intervensi secara luar jaringan (luring). Intervensi yang kami lakukan secara daring berupa diskusi-diskusi terkonsep dalam kelompok yang direkam melalui platform meeting online, selain itu kami memberikan video singkat terkait hal-hal yang perlu dilakukan dan dipersiapkan untuk beraktivitas di luar rumah pada era New Normal. Kemudian, kami juga melakukan rekaman diskusi dalam jaringan (daring) yang berkolaborasi dengan Tim Dokter dari Fakultas Kedokteran Universitas Airlangga, Surabaya. Dalam diskusi tersebut kami membahas keresahan-keresahan masyarakat secara umum seputar pandemi COVID-19 menuju Adaptasi Kebiasaan Baru (AKB). Rekaman dari diskusi-diskusi tersebut kemudian kami dipublikasikan lewat akun 
Instagram yang kami kelola. Sedangkan untuk intervensi yang dilakukan secara luar jaringan (luring), kami mengadakan bakti sosial dengan membagikan nasi kotak, masker, dan hand sanitizer kepada masyarakat Kelurahan Cempaka Putih Barat, Kecamatan Cempaka Putih, Jakarta Pusat.

\section{HASIL DAN PEMBAHASAN}

Keberadaan media sosial seperti Instagram memiliki potensi pemakaian yang meningkat di masa pandemi ini. Instagram kemudian dipandang sebagai media sosial dengan dampak yang luar biasa dan menjanjikan. Pemanfaatan media sosial ini pun semakin berkembang dan meningkat dengan adanya kondisi pandemi COVID-19. Hal ini kemudian mendorong KKN BBM Ke-62 Kelompok 270 koordinator 8 dalam membuat program berbasis online yang dapat membentuk berbagai opini, berbagi informasi dan inspirasi, menambah ilmu pengetahuan, membangun relasi dan kerjasama, meningkatkan partisipasi sosial di masyarakat, dan lain-lain melalui program QnA with Medical Personnel. QnA with Medical Personnel merupakan program kerja bersama tim dokter Fakultas Kedokteran Universitas Airlangga, yaitu dr. Cahyo Wibisono Nugroho, Sp.PD., FINASIM sebagai Staff Divisi Rheumatology - Ilmu Penyakit Dalam yang bertujuan agar masyarakat lebih berhati-hati, mengetahui lebih mendalam terkait COVID-19, dan menambah wawasan mengenai kesehatan khususnya di masa pandemi COVID-19. Untuk lebih menarik perhatian masyarakat, kelompok 270 mengundang tokoh atau tenaga ahli tentunya dalam bidang kesehatan untuk ikut serta dalam pembuatan video konsep QnA dan Sharing Session. Melalui partisipasi dari tokoh atau tenaga medis ini, diharapkan video yang akan dipublikasikan di media sosial akan lebih berdampak terhadap masyarakat. Adapun topik yang dibahas didalamnya, beberapa pertanyaan serta keluhan masyarakat mengenai kesehatan selama masa PSBB dan transisi ke arah AKB (Adaptasi Kebiasaan Baru) serta tentunya sangat berkaitan erat dengan pembahasan pandemi COVID-19.

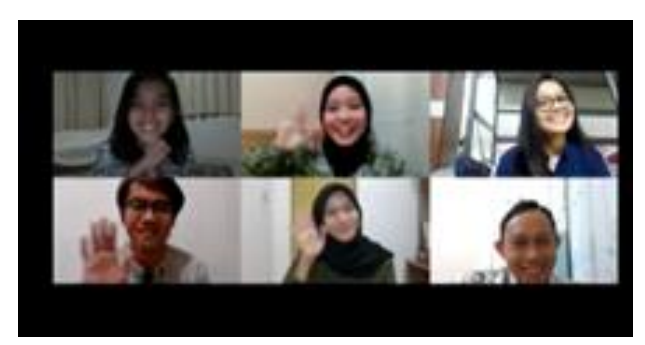

Gambar 1. Pelaksanaan QnA with Medical Personnel melalui Zoom Meeting

Teknis pelaksanaan QnA with Medical Personnel ini adalah secara online dengan memanfaatkan platform Zoom Meeting yang kemudian akan diunggah ke akun Instagram Alocanajkt. Proses rekaman video berhasil dilaksanakan pada Jum'at, 17 Juli 2020. Di dalam video, terdapat lima anggota kelompok 270 dan seorang dokter yang membahas informasi terkait COVID-19 dan new normal di Indonesia. Program ini dirancang dan direncanakan untuk memanfaatkan dengan adanya tim dokter yang ikut serta berpartisipasi mendukung serta memberikan informasi terkait COVID-19 lebih mendalam dan lebih akurat. Pelaksanaan QnA with Medical Personnel ini mempunyai durasi selama kurang lebih satu jam. 
Rafi Ramadhani Elgaputra, dkk: Implementasi Sosialisasi Covid-19 dalam Upaya Meningkatkan Kesadaran Masyarakat Terhadap Protokol Kesehatan di Kota Jakarta

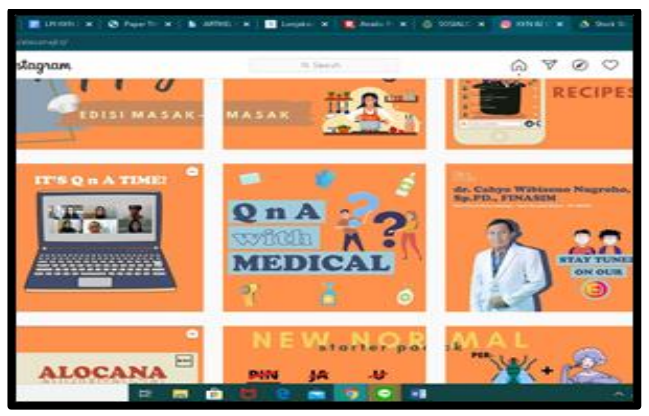

Gambar 2. Pengunggahan Video QnA with Medical Personnel di Instagram

Pengunggahan video yang berhasil dipublikasikan pada Minggu, 19 Juli 2020 melalui akun Instagram Alocanajkt didesain secara menarik untuk mendapatkan feedback yang baik dari para followers dengan cara menonton dan mempublikasikannya kembali, sehingga pesan dan informasi yang telah disampaikan mengenai kesehatan di masa pandemi tersampaikan dan dapat diaplikasikan dalam kehidupan sehari-hari.

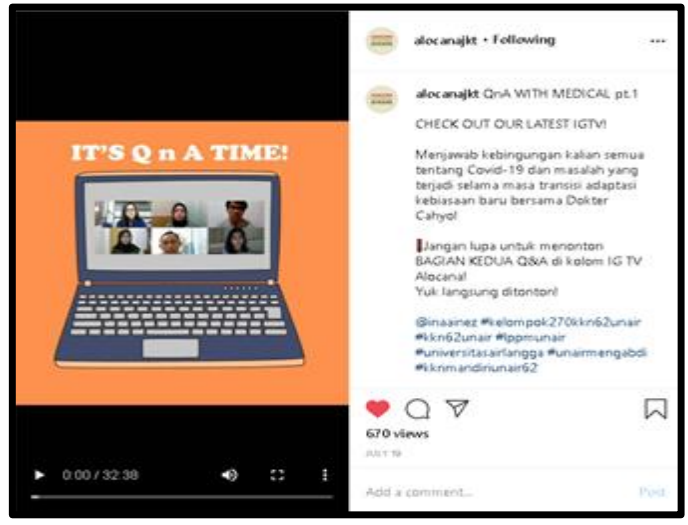

Gambar 3. IGTV QnA with Medical Personnel Part I

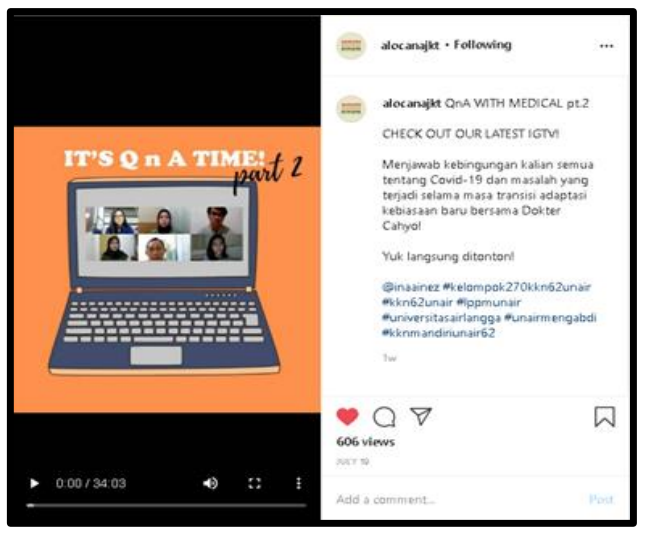

Gambar 4. IGTV QnA with Medical Personnel Part II

QnA with Medical Personnel mendapatkan antusias yang tinggi dari masyarakat pengguna aktif Instagram, hal ini dapat ditinjau dari jumlah views dengan total sebanyak 1276 views. Suatu isu, permasalahan kesehatan, dan rumor seputar COVID-19 di Indonesia yang disampaikan oleh kelompok 270 kepada tim dokter ini telah melebihi jumlah target yang telah direncanakan sebelumnya, yaitu sebanyak 100 views saja.

Rendahnya kemampuan literasi dan masih banyak orang yang tidak memiliki akses pada media-media informasi sehingga menyebabkan mereka memiliki minim pengetahuan atas merebaknya wabah COVID-19 dapat diatasi dengan memperkaya ilmu pengetahuan dan sosialisasi yang tepat. Di tengah keterbatasan aktivitas sosial yang dianjurkan oleh pemerintah dengan melakukan Pembatasan Sosial Berskala Besar (PSBB), social distancing, dan new normal dengan himbauan untuk menggunakan masker setiap bepergian keluar rumah menyebabkan masyarakat saat ini dihadapkan dengan sebuah lingkungan sosial baru yang harus bisa menyesuaikan diri sesegera mungkin. Agar menciptakan peningkatan kesadaran masyarakat terhadap bahaya COVID-19, perlu dilakukan sosialisasi secara terus menerus tidak hanya melalui kegiatan online yang telah dipublikasikan ke berbagai media sosial saja, melainkan juga 
edukasi publik secara langsung untuk membudayakan pola hidup bersih dan mengikuti aturan atau kebijakan pemerintah mengenai protokol kesehatan. Peran serta dan keterlibatan masyarakat secara langsung juga dibutuhkan untuk mendukung sikap kehati-hatian masyarakat dalam bertindak, kaya akan pengetahuan dan memiliki edukasi mengenai wabah Covid-19 sehingga virus COVID-19 dapat dengan cepat diatasi, ditanggulangi, serta diputus rantai penyebarannya, kemudian juga membantu serta mempermudah kerja Pemerintah. Sosialisasi secara langsung mempunyai dampak yang lebih bermanfaat, hal ini selanjutnya akan dijelaskan pada salah satu kegiatan yang diselenggarakan secara offline sekaligus sebagai acara penutupan kegiatan KKN BBM ke-62 Universitas Airlangga dari kelompok 270 koordinator 8, yaitu Alocaring.

Alocaring merupakan program kerja dalam rangka meningkatkan kesadaran masyarakat Cempaka Putih Jakarta terhadap pentingnya pencegahan penyebaran penularan virus COVID-19, sekaligus memfasilitasi masyarakat sekitar dalam penyediaan APD. Seperti yang telah diketahui, daerah Cempaka Putih Jakarta termasuk kedalam zona merah yang artinya zona ini perlu memiliki perhatian dan bentuk kepedulian yang lebih dari masyarakat lain untuk membantu meningkatkan kesadaran masyarakat terhadap kesehatan, serta mendukung terputusnya rantai penyebaran COVID-19 di daerah tersebut. Kelompok 270 akan membagikan sebanyak lima puluh makanan kotak, empat puluh hand sanitizer, dan empat puluh masker secara langsung kepada pihak-pihak yang membutuhkan, yaitu diantaranya adalah masyarakat dengan usia renta yang masih memiliki keperluan beraktivitas di luar rumah untuk bekerja, seorang tukang ojek offline dan online, pedagang kaki lima, supir bajaj, pemulung, dan lain-lain. Tidak hanya sekedar membagi-bagikan sejumlah barang tersebut, tetapi setiap anggota kelompok juga harus memberikan penyuluhan kepada masyarakat sekitar sebagai bentuk ajakan untuk tetap waspada terhadap virus COVID-19 serta menghimbau mereka untuk tetap menaati protokol kesehatan yang telah diberikan oleh pemerintah saat sedang beraktivitas di luar rumah. Dengan gerakan kecil ini, diharapkan dapat memberikan contoh dan pembelajaran yang bermanfaat kepada masyarakat sekitar Cempaka Putih Jakarta untuk bersama-sama bahu-membahu dalam mencegah penyebaran virus corona di lingkungannya. Untuk itu, pelaksanaan program Alocaring telah direncanakan minimal selama satu minggu untuk mengetahui kondisi keamanan daerah, survei beberapa produk yang perlu dibeli untuk kebutuhan yang akan diberikan, dan teknis pembagian serta sasaran pembagian yang dituju.

Melalui berbagai diskusi sebagai proses perencanaan, Alocaring berhasil dilaksanakan pada Rabu, 22 Juli 2020. Sebagai langkah pertama, kelompok 270 menyiapkan barangbarang keperluan yang akan disalurkan kepada masyarakat, yaitu masker dan hand sanitizer yang kemudian dimasukkan satu-persatu ke dalam plastik. Selanjutnya, kelompok 270 menyiapkan lima puluh kotak makanan yang telah dipesan dari hari sebelumnya. Seluruh anggota kelompok bersama-sama membagikan semua makanan dengan cara berkeliling di sekitar pemukiman warga, dimana banyak sekali ditemui supir bajaj, tukang ojek, dan warga lainnya yang sedang melakukan aktivitas. Saat melakukan pembagian, memang masih banyak ditemukan warga setempat yang belum menggunakan masker sebagai standar pelindung diri yang minimal harus dikenakan saat beraktivitas di luar selama masa pandemi. Disamping itu, kelompok 270 telah berhasil menyalurkan seluruh makanan, hand sanitizer, dan masker kepada masyarakat Cempaka Putih Jakarta serta berhasil menghimbau masyarakat setempat untuk tetap 
menjaga kesehatan, kebersihan, dan menaati protokol kesehatan selama pandemi COVID-19 berlangsung.

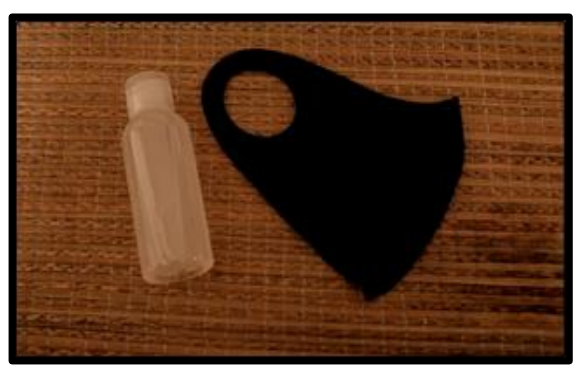

Gambar 5. Masker dan Hand Sanitizer Sebelum di Packing

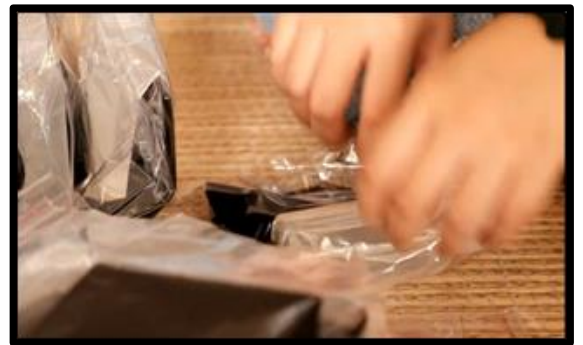

Gambar 6. Proses Packing Masker dan Hand Sanitizer yang Akan Dibagikan

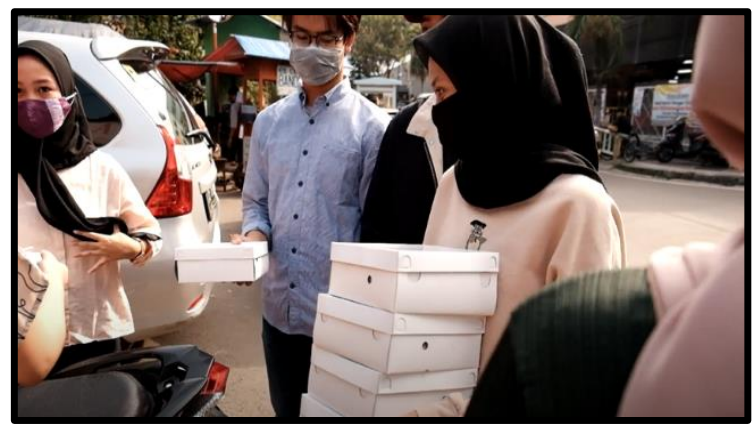

Gambar 8. Persiapan Pembagian Makanan, Hand Sanitizer dan Masker untuk Warga Cempaka Putih

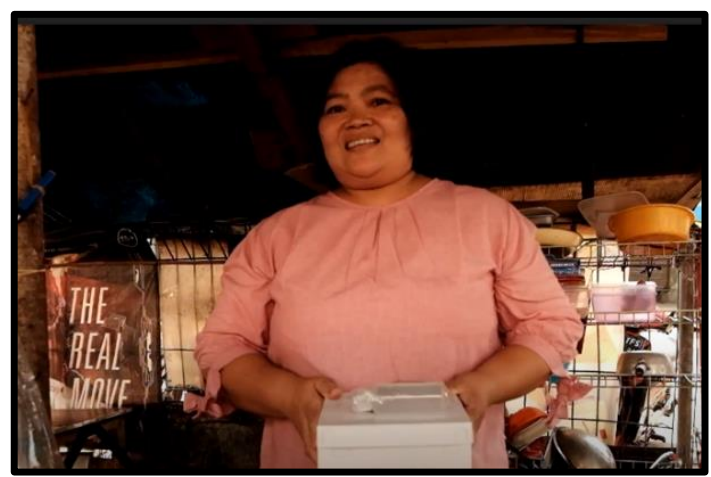

Gambar 10. Pembagian Makanan, Hand Sanitizer dan Masker untuk Pedagang Kaki Lima 


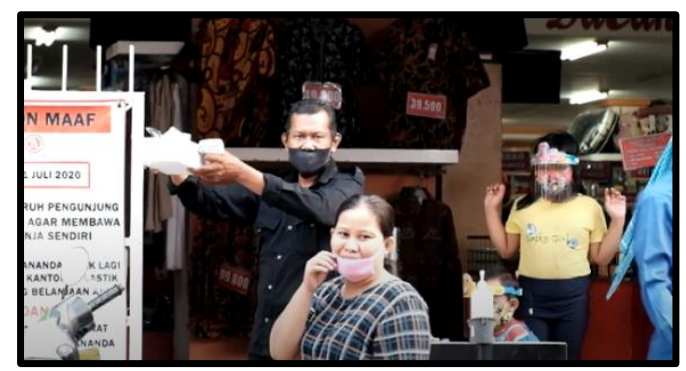

Gambar 11. Pembagian Makanan, Hand Sanitizer dan Masker untuk Satpam Pusat Perbelanjaan

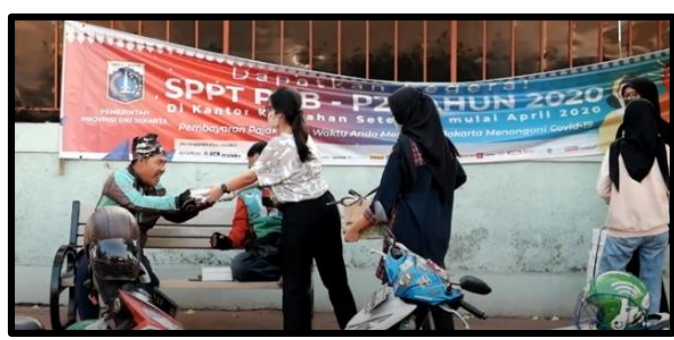

Gambar 12. Pembagian Makanan, Hand Sanitizer dan Masker untuk Pengemudi Ojek Online

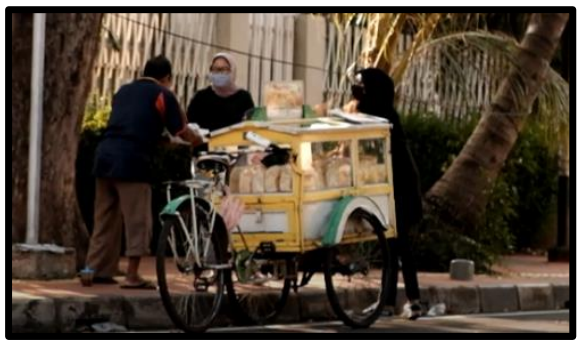

Gambar 13. Pembagian Makanan, Hand Sanitizer dan Masker untuk Pedagang Roti Keliling

Dapat diketahui dari berbagai dokumentasi di atas, masyarakat Cempaka Putih Jakarta memiliki antusias yang tinggi menyambut keberadaan kami yang ingin memberikan penyuluhan serta membagi-bagikan makanan beserta masker dan hand sanitizer kepada mereka. Mereka merasa senang atas bentuk kepedulian yang telah kelompok $270 \mathrm{KKN}$ BBM-62 UNAIR koordinator 8 berikan.

\section{PENUTUP}

\section{Kesimpulan}

Berangkat dari latar belakang masalah yaitu COVID-19 yang membuat masyarakat resah hingga diberlakukannya PSBB transisi yang harus selalu menunjang protokol kesehatan. Hal ini yang menjadikan tim KKN 62 UNAIR Kelompok 270 tergerak untuk memberikan edukasi melalui social media yang bertujuan agar masyarakat dapat semakin berhati-hati dalam melakukan sesuatu di masa pandemi ini dan semakin kaya akan pengetahuan terkait protokol kesehatan saat pandemi ini. Dalam mewujudkan hal tersebut metode yang digunakan tim KKN 62 UNAIR Kelompok 270 yaitu 4 intervensi secara jaringan (daring) dan 1 (satu) intervensi secara luar jaringan (luring). Kegiatan daring tersebut salah satunya yaitu QnA with Medical Personnel bersama tim dokter FK UNAIR, yaitu dr. Cahyo Wibisono Nugroho, Sp.PD., FINASIM sebagai Staff Divisi Rheumatology - Ilmu Penyakit Dalam. Program ini memiliki tujuan agar masyarakat lebih berhati-hati, mengetahui lebih mendalam terkait COVID-19, dan menambah wawasan mengenai kesehatan khususnya di masa pandemi COVID-19. Selain kegiatan daring intervensi secara luar jaringan yang kami lakukan yaitu program yang kami namakan ALOCARING, program ini bertujuan untuk meningkatkan kesadaran masyarakat Cempaka Putih Jakarta terhadap pentingnya pencegahan penyebaran penularan virus COVID-19, sekaligus memfasilitasi masyarakat sekitar dalam 
penyediaan APD. Sehingga terlihat jelas dalam pelaksanaan program ini juga mendapat umpan balik positif dari masyarakat yaitu terlihat dari masyarakat yang telah menyaksikan QnA tersebut dan antusias masyarakat yang tinggi terhadap program ALOCARING.

\section{Saran}

Melalui pelaksanaan program KKN 62 UNAIR Kelompok 270, terlihat bahwa masih dibutuhkan pergerakan dengan niat baik untuk membangun kesadaran masyarakat. Pergerakan dalam berbagai bidang, akan sangat membantu untuk menyebarkan informasi positif dalam menghadapi pandemi saat ini. Pandemi dalam skala besar, harus ditangani dengan penanggulangan yang besar juga, maka dari itu seluruh masyarakat perlu meningkatkan empati dan simpati. Seluruh kemajuan teknologi yang telah memfasilitasi untuk menyempitkan jarak, baik nya dimanfaatkan semaksimal mungkin untuk saling terkoneksi, diskusi, dan me-realisasi rancangan demi kebaikan.

Selain itu, saran untuk kegiatan yang akan diwujudkan kedepannya adalah, lakukan sosialisasi dengan merata. Merata bukan dalam hal geografis saja, melainkan merata dalam berbagai bidang. Tidak melulu bersosialisasi mengenai kesehatan dan bahaya pandemi COVID-19, tetapi dimaksimalkan juga dengan cara merancang finansial keluarga, menghadapi rupa informasi yang tersebar, dan menjaga mental agar tetap sehat di rumah.

\section{DAFTAR PUSTAKA}

Arditama, E., \& Lestari, P. (2020). Jogo Tonggo: Membangkitkan Kesadaran Dan Ketaatan Warga Berbasis Kearifan Lokal Pada Masa Pandemi Covid-19 Di Jawa Tengah. Jurnal Pendidikan Kewarganegaraan Undiksha, 8(2), 157-167.

Buana, D. R. (2020). Analisis Perilaku Masyarakat Indonesia dalam Menghadapi Pandemi Virus Corona (Covid-19) dan Kiat Menjaga Kesejahteraan Jiwa. Salam: Jurnal Sosial dan Budaya Syar-i, 7(3), 217-226.

Jakarta Tanggap Covid-19 (corona.jakarta.go.id) diakses pada Selasa, 28 Juli 2020.

Mardhia, D., Kautsari, N., Syaputra, L. I., Ramdhani, W., \& Rasiardhi, C. O. (2020). Penerapan Protokol Kesehatan dan Dampak Covid-19 Terhadap Harga Komoditas Perikanan dan Aktivitas Penangkapan. Indonesian Journal of Applied Science and Technology, 1(2), 80-87.

Putri, R. N. (2020). Indonesia dalam Menghadapi Pandemi Covid-19. Jurnal Ilmiah Universitas Batanghari Jambi, 20(2), 705-709.

Silalahi, A. (2020). Perubahan Pola Hidup Pada Situasi Covid-19 Adaptasi Pada Pola Hidup Normal Baru. Medan.

Telaumbanua, D. (2020). Urgensi Pembentukan Aturan Terkait Pencegahan Covid-19 Di Indonesia. Qalamuna: Jurnal Pendidikan, Sosial, dan Agama, 12(1), 59-70. 
Trisiana, A., \& Syaibani, I. (2020). Menumbuhkan Kesadaran Masyarakat Indonesia Untuk Memutus Rantai Penyebaran Wabah Covid-19. Jurnal Global Citizen: Jurnal Ilmiah Kajian Pendidikan Kewarganegaraan, 9(1), 51-62.

Tukan, R. A. (2020). Mengulik Perilaku 'bandel' masyarakat Di Tengah Pandemik Covid-19. Antologi dari Bumi Paguntaka: Covid-19: Dampak dan Solusi, 12.

Unknown. (2020). Lonjakan Social Commerce Selama Pandemi Covid-19. https://radarjogja.jawapos.com/2020/05/28/lonjakan-social-commerce-selamapendemi-covid-19/ diakses pada Selasa, 28 Juli 2020. 